Nigerian Journal of Technology (NIJOTECH)

Vol. 34 No. 3, July 2015, pp. $484-490$

Copyright@ Faculty of Engineering,

University of Nigeria, Nsukka, ISSN: 0331-8443

www.nijotech.com

http://dx.doi.org/10.4314/nit.v34i3.9

\title{
PERFORMANCE EVALUATION OF A BIOMASS STOVE USING PARTICULATE MATTER AND CARBON MONOXIDE EMISSION FROM BRIQUETTE AND FUEL WOOD
}

\author{
A. C. Igboanugo', M. U. Ajieh ${ }^{2,}{ }^{*}$ and S. O. Azi $^{3}$ \\ 1 Department of Production Engineering, University of Benin, Benin City, Edo State. NiGERIA \\ 2 National CEntre for Energy and EnVironment (EnERgy Comm. of Nigeria), BEnin City, Edo State. NiGERIA \\ 3 Department of Physics, Faculty of Physical Sciences, University of Benin, Benin City. Edo State. NigERIA \\ E-mail addresses: ${ }^{1}$ anthony.igboanugo@uniben.edu, ${ }^{2}$ mike.ajieh@gmail.com, ${ }^{3}$ ogochukwuazi@uniben.edu
}

\begin{abstract}
In most developing countries like Nigeria, the use of biomass cooking stove is predominant. This is often done in a poorly ventilated kitchen or thatched houses sometimes occupied by up to 3-7 households. Researchers have proved that smoke and other emissions resulting from fuel wood in traditional stoves have led to increase in health hazards which include acute carbon monoxide (CO) poisoning diseases, Acute Lower Respiratory Infections among others. This study examines the emission of particulate (PM) and CO from briquette and fuel wood. Water Boiling Test (WBT) was carried out to test the performance of both fuels at ambient temperature and standard pressure. Test results show the burning rate of briquette fuel is $20.5 \mathrm{~g} / \mathrm{min}$ and that of fuel wood to be $16.8 \mathrm{~g} / \mathrm{min}$. The thermal efficiency of briquettes and fuel wood are $14.5 \%$ and $31.1 \%$ respectively. Thermal efficiency of $31.1 \%$ shows significant improvement when compared with available stoves. Increasing thermal efficiency will generally reduce fuel requirement during cooking which implies less time and less exposure to PM and CO emissions. Analysis of test result using MATLAB shows that fuel wood emitted more particulate matter than briquette. The mean distribution of particulate matter for briquette (PM-B) and that of fuel wood (PM-F) was analyzed using Paired Two Sample statistical test. CO emission for briquette (CO-B) and fuel wood (CO-F) was analyzed respectively. The statistical analyses shows higher mean values for $P M-F$ and $C O-F$ and lower mean values for $P M-B$ and CO-B respectively. High thermal efficiency translates to less exposure to PM and CO emission which reduces significantly, risk to health accruing to the use of briquette and fuel wood on cook stove.
\end{abstract}

Keywords: biomass stove, thermal efficiency, fuel wood, briquette, particulate matter, carbon monoxide, emissions, burning rate

\section{INTRODUCTION}

Open fires and primitive stoves have been used for cooking since the beginning of human history. These stoves have come in various sizes and styles which require biomass as feed stock. Nearly 2 billion people, constituting about a third of humanity, continue to rely on biomass fuels and traditional technologies for cooking and heating $[9,1]$. Biomass smoke contains a large number of pollutants and known health hazards which includes; particulate matter, carbon monoxide, nitrogen dioxide, formaldehyde and polycyclic organic matter, such as benzo [a] pyrene, a carcinogen, as described in Ezzati [21], Smith [13] and Zhang [16].
This is usually in a poorly ventilated space leading to exposure to air pollutants in form particulate matter (PM) especially those greater than $2.5 \mathrm{ug} / \mathrm{m}^{3}$ in size and carbon oxides $\left(\mathrm{CO}\right.$ and $\left.\mathrm{CO}_{2}\right)$ [13]. Report of Smith [22] suggests that emission from biomass presents a high health risk for acute lower respiratory infection (ALRI), chronic obstructive pulmonary disease (COPD), cataracts, lung cancer and cardiovascular disease. A publication of the World Health Organization (WHO) [10], estimates that emissions from fuel wood contributes nearly $3 \%$ to the total global burden of diseases resulting to 1.6 million premature deaths each year, including 900,000 
children under the age of five (5). In addition, the seemingly unending perennial fuel crisis in Nigeria has drawn attention to the need for energy experts to concentrate on producing viable alternatives and/or complements kerosene and cooking gas for domestic cooking [11]. While many developed countries tend to focus on domestic energy security or decarburizing their energy mix, developing countries are still seeking to secure enough energy to meet basic human needs. In developing countries, access to affordable and reliable energy services is fundamental to reducing poverty and improving health, productivity, enhancing competitiveness and promoting economic growth. Despite these, billions of people are without basic modern energy services, lacking reliable access to either electricity or clean cooking facilities. Several research attempts have been done on stove designs and kitchen layout with the view to reducing carbon emissions and improving cross ventilation when cooking. Empirical study of Ezzati [21], shows that switching from conventional three-stone fire to improved clean cook stove can considerably reduce the risk of ARI and ALRI. Beside the economic and environmental considerations, the main reason motivating the various developmental efforts in the design of biomass improved clean cookstove is the health factor [7]. Venkataraman [6] strongly agrees with Joseph [7] and opines that clean cookstove technology is capable reducing half a million deaths due to respiratory and other illnesses linked with particulate and carbon emissions.

In Nigeria, there is the popular mud stove which is similar to the Kilakala stove in Tanzania $[5,12]$. One of the major disadvantages of the mud stove is that it is not movable. The Kenya Ceramic Jiko (KCJ), one of the most successful urban stove projects in the Eastern African region, was reported to have a useful heat of about 25-40 \% of the heat generated [8]. KCJ represents a significant increase when compared to three-stone open fire which directs only about 5-10\% of the heat generated from the fire to the cooking pot. There have been commendable efforts from research centers of Energy Commission of Nigeria (ECN) on energy efficient cook stoves. One of such research attempts is the two-pot stove which is similar to the Improved Vented Mud stove (IVM) with chimney. The IVM has average thermal efficiency values between 10 to $23.5 \%$.

Of these research efforts, very little have been done to assess the amount of emissions associated with the use of biomass fuel on stoves. Essentially, this paper focuses on the performance evaluation of fuel briquette and fuel wood on a rocket type biomass stove which was designed and fabricated at the National Centre for Energy and Environment (NCEE), a research Centre of the Energy Commission of Nigeria (ECN). In accordance with the WHO [10], health impacts associated solid wood based fuel is reduced through improvement and/or change of technology. Bailis [4] and Dutta [15] strongly agreed with emission reduction capacity of improved clean cookstove and fuel quality. Against this background, briquette and fuel wood were tested on NCEE Improved clean cookstove as shown in Figure 1 for particulates and carbon emissions in relation to their thermal efficiency. Water Boiling Test (WBT) using the Indoor Air Pollution (IAP) meter of the Aprovecho Research Centre which was installed at the International Centre for Energy, Environment and Development (ICEED), Afikpo for performance evaluation.

\section{MATERIALS AND METHODS}

\subsection{Description of the Biomass Stove}

The Figures 1 and 2 shows the diagram of the biomass stove and the skeletal frame respectively. The biomass stove is a rocket type with the following features; it operates on natural buoyant force of convection, it maintains constant cross sectional area throughout the stove which is as obtainable in rocket stove designs, creating an air inlet to speed up draught and enhance the combustion process, reduction in the gap between the pot suspender and the stove, reduction in the amount of heat loss using fiber glass as insulator and introduction of conical flame connector to reduce heat loss and smoke pollution as well as reduction in the size and weight of the stove for ease of movement. The combustion chamber is encased in mild steel fitted with fiberglass for insulation. The fuel bed or reservoir is a cylindrical shape and placed inside the stove where combustion of the fuel takes place. The stove cover is mounted on the cylindrical component to enhance heat retention during cooking. The ash filter consists of holes of diameter $2 \mathrm{~cm}$ through which ashes drop to the ash collector. The flame connector is welded to the upper chamber of the cylindrical cone. Essentially, the idea is to concentrate the heat released to the pot. An L-shaped pot suspender is attached on a ring top of the stove to reduce heat loss during cooking. It has external and internal diameter of $20 \mathrm{~cm}$ and $19 \mathrm{~cm}$ as shown in Fig. $2 \mathrm{~b}$. This is responsible for keeping the pot in position and also create interface between the heat released and the pot. The fuel feeder is a rectangular grove created to allow fuel and air 
inlet and to ensure that any smoke associated with the heat is released before it reaches the pot. A drawer is incorporated at the base to facilitate the removal of ash and collected at the tray.

The ash filter is a metal frame, its function is to hold the fuel in position and more so, filter off the fuel ash which is collected and used for agricultural cultivation. It is made from mild steel sheet of $2 \mathrm{~cm}$ thick. Sufficient holes were drilled on the plate for easy air passage. The ash filter is $25 \mathrm{~cm}$ in diameter and supported by rods welded to the plate. The stove housing is $20 \mathrm{~cm}$ in external diameter and $19 \mathrm{~cm}$ internal diameter, welded to it is $5 \mathrm{~cm} \times 4 \mathrm{~cm} \mathrm{~L}$-shaped auxiliary which is mounted on the stove cove. A conelike structure with circular holes was created in it with height of $15 \mathrm{~cm}, 25 \mathrm{~cm}$ diameter and an upper diameter of $15 \mathrm{~cm}$ made up of steel materials welded to the housing unit with many holes drilled in it for ease of circulation of secondary air. The stove frame was fabricated from stainless steel sheet of $20 \mathrm{~mm}$ in thickness; it is a hollow cylinder of $500 \mathrm{~mm}$ in height and $200 \mathrm{~mm}$ in diameter. Two handgrips are attached to the stove housing to ease carriage. The ash dissipated from combustion is filtered off and collected with the ash collector.

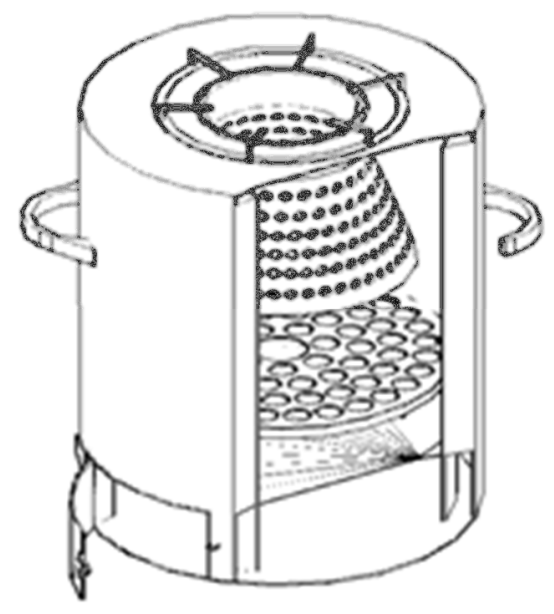

Figure 1: Biomass Stove

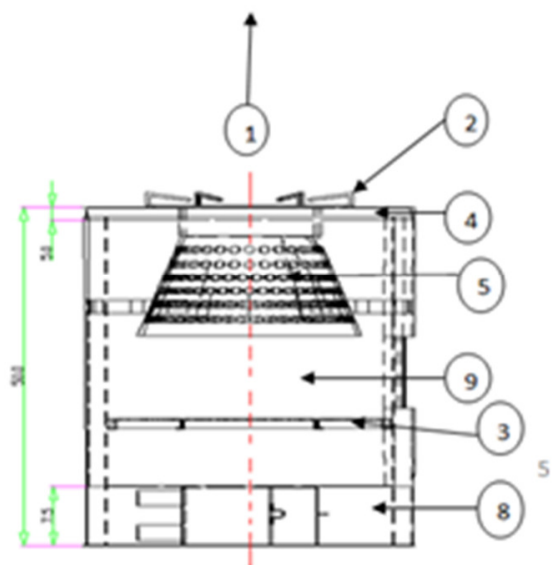

Figure 2: Stove skeletal frame
Table 1: Parts Description

\begin{tabular}{ll}
\hline Item No & Item Description \\
\hline 1 & Ash chamber gate \\
2 & Stove cover \\
3 & Ash filter \\
4 & Pot suspender \\
5 & Flame connector \\
6 & Handle \\
7 & Fuel gate \\
8 & Ash collector unit \\
9 & Fuel reservoir \\
\hline
\end{tabular}

The diameter of the combustion chamber is such that it is smaller than the pot seat or the external diameter of the smallest pot that can be used on the stove to ensure that the maximum amount of heat is transferred to the pot. The height of the flame connector is adjusted to allow for enough time for the combustion of the burning fuel before it reaches the base of the pot on the stove.

\subsection{Water Boiling Test}

Indoor Air Pollution (IAP) meter of the Aprovecho Research Centre was installed at the International Centre for Energy, Environment and Development (ICEED), Afikpo and was used to perform Water Boiling Test (WBT). The essence is to measure the overall performance of a cook stove. There are several versions of the water boiling test. In general the test consists of three phases which are: (1) bringing water to a boil from a cold start; (2) bringing water to a boil when the stove is hot; and, (3) maintaining the water at simmering (constant) temperatures. In this case, the water was brought from cold start to boiling temperature under Laboratory Emission Monitoring System (LEMS). The LEMS model is an ideal test for kitchen environment. It measures the total emissions produced during stove combustion. The stove is placed under a hood which collects the emissions and air from the laboratory. The flow rate and exhaust temperature are measured in the exhaust tube. A fraction of the flow through the system is drawn by a suction pump through a sample line to the sensors. Separately, a thermocouple suspended through the pot led into the water to measure the pot temperature. Carbon monoxide (CO) is measured with the aid of an electrochemical cell sensor. This cell has a reference terminal and requires a potentiostatic controller. The carbon dioxide $\left(\mathrm{CO}_{2}\right)$ sensor uses non-dispersive infrared (NDIR) to measure $\mathrm{CO}_{2}$ concentration and outputs voltage. It is self-calibrating, with pure Nitrogen gas used for a zero reference. The particulate matter (PM) was measured using gravimetric system. 
A vacuum pump pulls a sample through the sample line and the critical orifice, which holds the flow at a steady rate of $16.7 \mathrm{~L} / \mathrm{min}$. A cyclone particle separator is used to ensure that all particulate matters greater or equal to $2.5 \mathrm{ug} / \mathrm{m}^{3}\left(\mathrm{PM}_{2.5}\right)$ are collected on a glass fiber filter while the pump is on. The filter is pre and postweighed to calculate the total $\mathrm{PM}_{2.5}$ mass.

\subsection{Fuel Considerations}

In this experiment, two fuel types were considered namely; briquette sawdust and fuel wood. In accordance with European Standard (EN14961), briquette is a densified biofuel made with or without additives in the form of cubiform or cylindrical units ( $\varnothing \geq 25 \mathrm{~mm}$ ) produced by compressing pulverized wood. In this case, the briquette was made from sawdust collected from sawmills. It was prepared by mixing known quantity of sawdust with water and starch as binder. The briquettes were sun dried to ensure proper curing and uniform moisture content. Fuel woods are cut and split oven ready pieces of wood usually between $100 \mathrm{~mm}-1000 \mathrm{~mm}$ by size. Essentially, both fuels are from wood sources. Sawdust is a combination of several woods (soft or hard) generated from cutting wood to shapes and sizes. In other words, briquettes made from sawdust have similar chemical properties with that of wood except for variations in their moisture content. Wood is composed of many chemical components, primarily extractives, carbohydrates, and lignin, which are distributed non-uniformly as the result of anatomical structure. Lignins can be broadly divided into three classes: softwood (gymnosperm), hardwood (angiosperm) and grasses (graminaceous). Sawdust is a combination of soft and hardwood. Generally, guaiacyl lignin is found in softwoods while guaiacylsyringyl lignin is present in hardwoods [14]. In several cases, sawdust has been used either in its raw state or in densified state to fire cook stoves. Concerns on emission resulting from its use or the use of fuel wood has led to several research attempts aimed as unraveling the differences in amount of carbon and particulate matters arising from wood based fuels when used for cooking.

In this study, equal volume of water (5L) was measured in consonance with equal weight of briquette and fuel wood respectively. Weighed fuel wood was introduced into the combustion chamber and ignited with small pieces of shavings. The briquette was ignited with kerosene after which sufficient time was allowed for fire to build strength before subjecting it to the LEMS testing guidelines of the Aprovecho Research Centre, USA. The time, temperature of the surrounding and the initial temperature of the water were noted.

\subsection{Results and Discussions}

The PM and CO data for briquette and fuel wood were measured and recorded using LEMS at time intervals as shown in Table 2.

\begin{tabular}{|c|c|c|c|c|}
\hline $\begin{array}{l}\text { Time } \\
(\mathrm{Sec})\end{array}$ & $\begin{array}{c}\text { PM-B } \\
\left(\mathrm{ug} / \mathrm{m}^{3}\right)\end{array}$ & $\begin{array}{c}\text { PM-F } \\
\left(\mathrm{ug} / \mathrm{m}^{3}\right)\end{array}$ & $\begin{array}{l}\text { CO-B } \\
\text { (ppm) }\end{array}$ & $\begin{array}{l}\text { CO-F } \\
\text { (ppm) }\end{array}$ \\
\hline 1.0 & -10 & -7 & 53 & 106 \\
\hline 3.0 & -9 & -7 & 47 & 114 \\
\hline 5.0 & -11 & -7 & 39 & 114 \\
\hline 7.0 & -7 & -7 & 38 & 113 \\
\hline 9.0 & -10 & -7 & 32 & 116 \\
\hline 11.0 & -10 & -6 & 27 & 113 \\
\hline " & " & " & " & " \\
\hline " & " & " & " & " \\
\hline " & " & " & " & " \\
\hline 1439.0 & 476 & 47 & 5785 & 2889 \\
\hline
\end{tabular}

Table 2 shows the result obtained for Water Boiling Test (WBT). Details of the test show that briquette took sixty minutes to boil 5L of water. At the same condition of test, it took twenty four minutes to boil the same quantity of water when fuel wood was used. Further result for fuels in terms of burning rate, thermal efficiency, specific fuel consumption, temperature corrected specific consumption; firepower and equivalent dry fuel consumed are shown in Table 3. The thermal efficiency of the stove when tested on briquette is $15 \%$ while that of fuel wood is $31 \%$. Thermal efficiency of the stove suggests that this stove is suitable for use a fuel wood stove.

\section{Table 3: Water Boiling Test (WBT) Results}

\begin{tabular}{lcc}
\hline Test Parameters & $\begin{array}{c}\text { Briquette } \\
\text { Fuel }\end{array}$ & $\begin{array}{c}\text { Fuel } \\
\text { Wood }\end{array}$ \\
\hline Time to boil Pot (min) & 60.0 & 24.0 \\
Burning rate (g/min) & 20.5 & 16.8 \\
Thermal efficiency (\%) & 0.145 & 0.311 \\
$\begin{array}{l}\text { Specific fuel consumption } \\
\text { (g/litre) }\end{array}$ & 297.45 & 88.37 \\
$\begin{array}{l}\text { Temp-corrected specific } \\
\text { consumption (g/litre) }\end{array}$ & 322.85 & 92.82 \\
$\begin{array}{l}\text { Firepower (watts) } \\
\begin{array}{l}\text { Equivalent Dry Fuel Consumed } \\
\text { (g) }\end{array}\end{array}$ & 6298.40 & 5165.8 \\
& 1231.36 & 403.98 \\
\hline
\end{tabular}


Comparison of the thermal efficiency with wood stoves like KCJ, IVM and other locally accessible stoves shows considerable improvement. In accordance with Grieshop [19], Traditional stoves can be improved in three ways namely; (i) increasing thermal efficiency, (ii) reducing specific emissions and (iii) increasing ventilation. Data generated from LEMS were plotted using MATLAB to examine the distribution of PM and CO. Figure 3 shows sinusoidal curve for both PM and CO. The spikes on the curve represent perturbations caused by fuel toggle in the cold start, hot start and/or simmering in other to sustain or increase firepower. At the point when the fire is perturbed, PMs are set in motion leading to formation of fly ash within the combustion chamber and through the fire exit.

Initially, particles of the fly ash experience poor combustion which increases the formation of $\mathrm{CO}$. At increased firepower, the curve returns to a fairly normal sinusoidal curve. In addition, it took about eight minutes after fire start up for briquette to gain strength. This is due to the moisture content and effects of the binder which has the ability to influence the burning rate [20]. On the contrary, fuel wood picked up faster in terms of firepower which is largely responsible for the time differential in taking the water to boiling temperature at cold start.

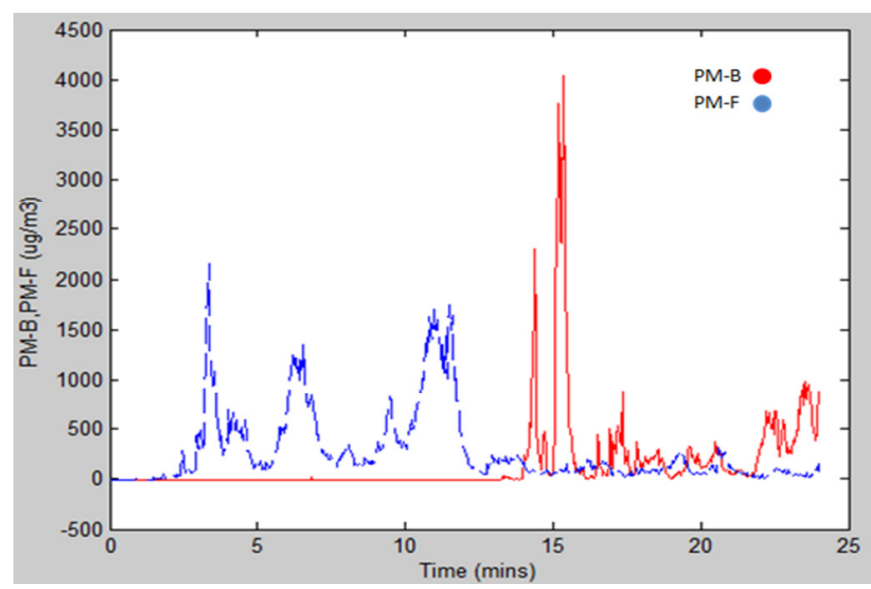

Figure 3: PM for Briquette and Fuel Wood

Furthermore, plot of the PMs for both fuels were represented with box plot as shown in Figure 9. It shows that fuel wood has a mean percentile higher than that of briquette which again can be affected by type of stove as shown in Johnson [17] and Wang [22]. Comparison of both plot shows that fuel wood has more spikes at wider range which is a resultant of perturbation.

The distribution of PM for both fuels was fit using paired t-test as shown in Table 4.

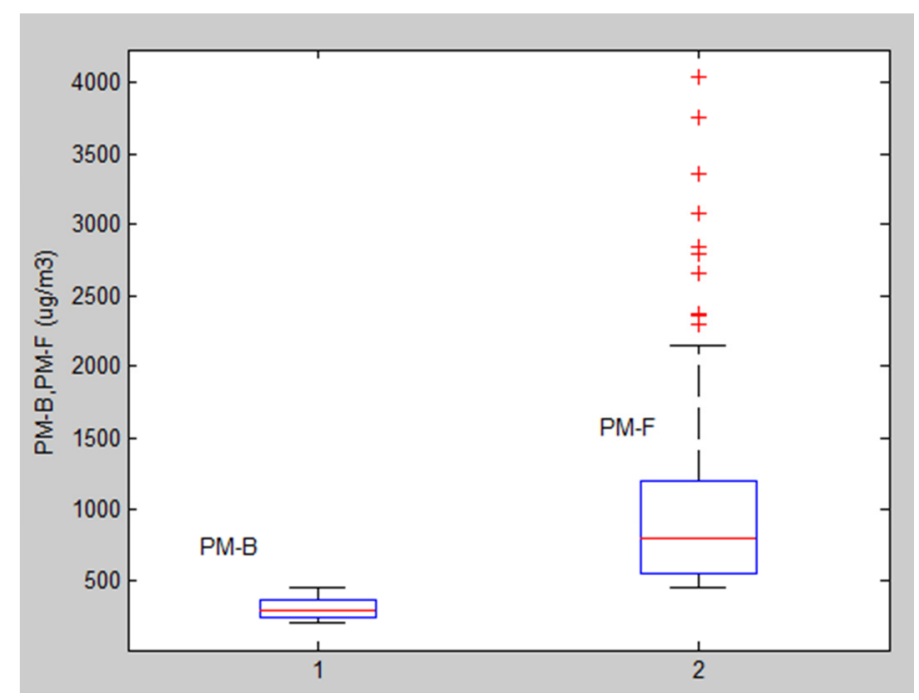

Figure 4: Box Plot of PM for Briquette and Fuel Wood

Table 4: Paired Two Sample for Mean

\begin{tabular}{lrr} 
& \multicolumn{1}{c}{ PM-B } & \multicolumn{1}{c}{ PM-F } \\
\hline Mean & 149.2538 & 274.9875 \\
Variance & 170647.6 & 136459.7 \\
Observations & 721 & 721 \\
Pearson Correlation & -0.20677 & \\
Hypothesized Mean & 0 & \\
Difference & 720 & \\
df & -5.54872 & \\
t Stat & $2.02 \mathrm{E}-08$ & \\
P(T<=t) one-tail & 1.646973 & \\
t Critical one-tail & $4.05 \mathrm{E}-08$ & \\
$\mathrm{P}(\mathrm{T}<=\mathrm{t})$ two-tail & 1.963264 & \\
$\mathrm{t}$ Critical two-tail & & \\
\hline
\end{tabular}

PM-B: Particulate emissions for briquette,

PM-F: Particulate emissions for fuel wood

Particulate matters emission differ significantly between briquettes fuel and fuel wood. This implies that both feed stock exhibited varying emission level which is in line with Dutta [15] and Ezzati [21]. From the mean, PM-F emitted more particulate matter emissions when compared to emission from fuel briquette which corroborates the mean value of the box plot as shown in Figure 4 .

The behavior of briquettes and fuel wood in terms of CO formation is as shown in Figure 5. It followed the same pattern as the PM with high sensitivity to perturbation and corresponding spikes on the curve. The distribution of $\mathrm{CO}$ for both fuels was fit using normal distribution and the result is as shown in Table 3. 


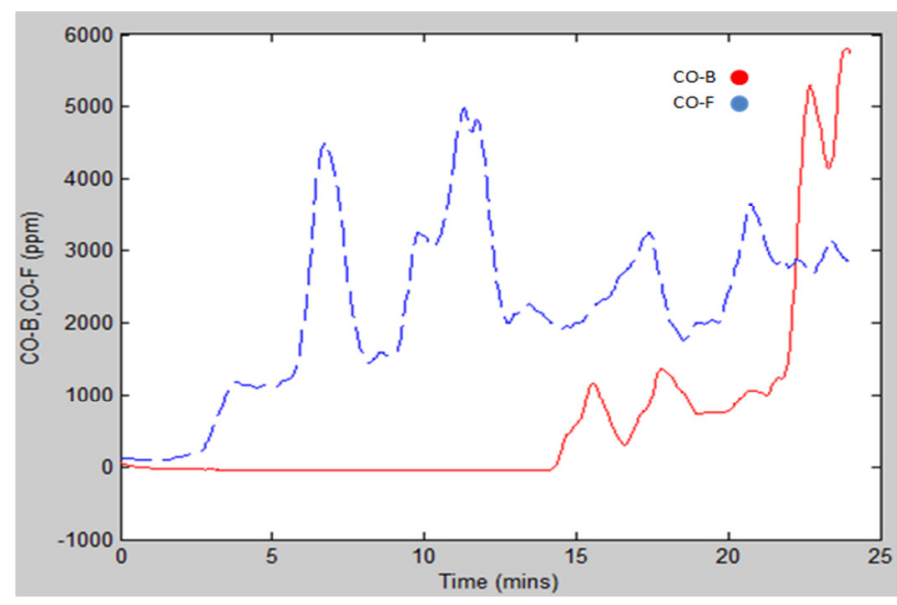

Figure 10: CO for Briquette and Fuel Wood

Table 5: Paired Two Sample for Mean

\begin{tabular}{lcc}
\hline & CO-B & CO-F \\
\hline Mean & 631.516 & 2191.877 \\
Variance & 1691823 & 1391547 \\
Observations & 721 & 721 \\
Pearson Correlation & 0.231847 & \\
Hypothesized Mean & & \\
Difference & & \\
Df & 720 & \\
t Stat & -27.2047 & \\
P(T<=t) one-tail & $6 \mathrm{E}-113$ & \\
t Critical one-tail & 1.646973 & \\
$\mathrm{P}(\mathrm{T}<=\mathrm{t})$ two-tail & $1.2 \mathrm{E}-112$ & \\
$\mathrm{t}$ Critical two-tail & 1.963264 & \\
\hline
\end{tabular}

CO-B: Carbon monoxide emissions for briquette,

CO-F: Carbon monoxide emissions for fuel wood

The mean of CO-F for fuel wood is 2191.877 and that of CO-B for briquette is 631.516. The implication is that fuel wood emitted more CO than briquette fuel. This means that carbon emissions differ significantly between briquettes fuel and Fuel wood. This result further shows that both feed stock exhibited varying emission level. Nonetheless, fuel wood took less time to boil when compared to briquette which suggests that over the time lag before the boiling temperature, briquette may have a higher cumulative CO than that of wood fuel for the same quantity of water which agrees with the publication of Zhang [16] on exposure potential of $\mathrm{CO}$ as well as in Ezzati [21]

\section{CONCLUSION}

Water Boiling Test (WBT) was used to measure the overall performance of a cook stove using the IAP meter to monitor the emission of PM and CO from two fuel feed stocks namely; briquette and fuel wood. The water was brought from cold start to boiling temperature under Laboratory Emission Monitoring System (LEMS). The LEMS model is an ideal test for kitchen environment and measures the total emissions produced during stove combustion. The result of tested stove shows that the burning rate of briquette fuel is $20.5 \mathrm{~g} / \mathrm{min}$ and that of fuel wood is $16.8 \mathrm{~g} / \mathrm{min}$. The thermal efficiency of briquettes and fuel wood are $14.5 \%$ and $31.1 \%$ respectively. Thermal efficiency of stove shows a higher suitability fuel wood than briquette fuel. In addition, thermal efficiency of $31.1 \%$ shows significant improvement when compared with available stoves. Increasing thermal efficiency will generally reduce fuel requirement during cooking which implies less time and less exposure to PM and $\mathrm{CO}$ emissions. Particulates and carbon emissions are products of incomplete combustion which are hazardous to health. Less exposure to PM and CO emission is of considerable importance in the reduction of risks to health accruing to the use of briquette and fuel wood on cookstove. The particulate matter for briquette (PM-B) in Figure 4typically shows low thermal efficiency of the fuel while the particulate matter for fuel wood is higher with higher thermal efficiency. Essentially, increase or decrease in thermal efficiency is predicated on design considerations. The primary air inlet and secondary air inlet to the combustion chamber have a fundamental influence on the thermal efficiency which again, has appreciable influence on PM and CO emissions. The results of the WBT analyzed and plotted using MATLAB shows rise in the PM until perturbation occurred either in the cold start, hot start and simmering stage. The behavior of the $\mathrm{CO}$ was similar to that of PM. Test of hypotheses shows that in $\mathrm{H}_{0}$, there is no significance in the emission of PM between briquettes fuel and fuel wood. Again in $\mathrm{H}_{1}$, there is no significance in the emission of $\mathrm{CO}$ between briquettes fuel and fuel wood. Result of paired sample t-test shows that for both fuels, fuel wood emitted more $\mathrm{PM}$ and $\mathrm{CO}$ respectively.

\section{REFERENCES}

[1] J.-F.K. Akinbami, M.O. Ilori, T.O. Oyebisi, I.O. Akinwumi, and 0. Adeoti. Biogas energy use in Nigeria: current status, future prospects and policy implications. Renewable and Sustainable Energy Reviews 5(1): 97-112 (2001).

[2] Aprovecho Research Centre, USA

[3] International Centre for Energy, Environment and Development (ICEED), Afikpo 
[4] R. Bailis, D. Ogle, N. MacCarty, and D. Still. The Water Boiling Test (WBT) version 4.12, Household Energy and Health Programme, Shell Foundation (2003), revised (2009).

[5] E. Crewe. Fuel wood stove project. Women Training Center, Christian Council of Tanzania, Review and Recommendations, Intermediate Technology Development Group (ITDG), Rugby, UK (1990).

[6] P. Venkataraman and S.N. Srinivas (Eds.). Tata Energy Research Institute (TERI), New Delhi, India (1997).

[7] S.K. Joseph, P. Krishna and H.B. Van der Zann. Bringing stovesto the people. ACTS Press and the Foundation for Wood Stove Dissemination (FWD), Nairobi, Kenya (1990).

[8] D.M. Kammen and B. Fayemi Kammen. Energy, food preparation and health in Africa: The roles of technology, education, and resource management. African Technology Forum 6(1): 11-14 (1992).

[9] S. Momoh and J. Soaga. Biomass energy consumption in Nigeria: Integrating demand and supply. Nigerian Journal of Renewable Energy 7(1 \& 2): 78-82 (1999)

[10] WHO. Pollution from Biomass Fuel. Working Papers from a WHO Consultation, pp. 89-104. World Health Organization (WHO), Geneva, Switzerland (2006).

[11] A.0. Olorunsola. The development and performance evaluation of a briquette burning stove. Nigerian Journal Renewable Energy 7(1 \& 2): 91-5 (1999).

[12] T. Otiti. Improved stoves in Tanzania, Stove Notes 6, FWD and ACTS Press, Nairobi, Kenya (1991).

[13] K.R. Smith. Fuel combustion, air pollution exposure, and health: The situation in developing countries. Annual Review of Energy and Environment, 18: 529-66 (1993).

[14] C. Ververis, K. Georghiou, N. Christodoulakis, P. Santas, R. Santas. Fiber dimensions, lignin and cellulose content of various plant materials and their suitability for paper production. Industrial Crops and Products 19 (245-254).

[15] K. Dutta, K. N. Shield, R. Edward \& K. R. Smith. Impact of improved biomass cookstoves on indoor air quality near Pune, India.Energy for Sustainable Development, Volume XI No. 2 (2007).

[16] J. Zhang, K.R. Smith, R. Uma, Y. Ma, V.V.N. Kishore, K. Lata, M.A.K. Khalil, R.A. Rasmussen, S.T. Thorneloe. Carbon monoxide from cookstoves in developing countries: 2. Exposure potentials. Chemosphere: Global Change Science 1 (1999) 367-375

[17] N. G. Johnson, K. M. Bryden. Factors affecting fuel wood consumption in household cookstoves in an isolated rural West African village. Energy 46 (2012) $310-321$.

[18] World Bank: Household Cookstoves, Environment, Health, and Climate Change: $A$ New Look at an Old Problem (2011).

[19] A. P. Grieshop, J. D. Marshall, M. Kandlikar. Health and climate benefits of cookstove replacement options. Energy Policy 39 (2011) 7530-7542

[20] G. Amaral-Labat, A. Szczurek, V. Fierro, N. Stein, C. Boulanger, A. Pizzi, A. Celzard.Pore structure and electrochemical performances of tannin-based carbon cryogels. Biomass and Bioenergy 39 (2012) $274-282$

[21] M. Ezzati and D. M. Kammen. Household Energy, Indoor Ai $r$ Pollution, and Public Health in Developing Countries. Resources for the Future, Washington DC, (2002) $02-26$

[22] Y. Wang, A. J. Gadgil and T. W. Kirchstetter. Effect of Change in Cookstove Types on Visibility - Case Study of the Berkeley-Darfur Stove and Three-Stone Fire. Lawrence Berkeley National Laboratory. Berkeley, CA, (2012) 